\author{
О.А. Дакі, А.О. Дорошева, В.М. Іваненко, В.І. Чебан
}

Державний університет інфраструктури та технологій, Київ

\title{
АГЕНТООРІЄНТОВАНА МОДЕЛЬ РЕАЛІЗАЦІЇ СИСТЕМИ ПІДТРИМКИ ПРИЙНЯТТЯ РІШЕННЯ БЕЗПЕКИ СУДНОВОДІННЯ
}

В статті розглянуто моделі та методи побудови системи підтримки прийняття рішення безпеки судноводіння з використанням мультиагентних систем, щуо відповідає сучасному напрямку розвитку інтелектуальних інформаційних технологій - побудови агентоорієнтованих систем. Визначено, що система безпеки судноводіння є ієрархічною слабоформалізуємою системою, яка є результатом взаємодї часто суперечних один одному по изілям функиіонування елементів, і має множину неявних прямих $і$ зворотних зв'язків. Для роботи в таких умовах проєктуєма система підтримки прийняття рішень повинна містити ряд інформаційних баз знань: нормативну, експертну і прецедентну. Відмічено, щзо реалізація процесу забезпечення безпеки судноводіння представляє собою складну задачу кооперативної неантагоністичної взаємодії з розподіленим прийняттям рімень, для якої критично важливим стає забезпечення координації такої взаємодії в умовах иілеспрямованої поведінки учасників, щуо намагаються забезпечити безпеку руху. Рімення даного завдання може бути реалізоване з використанням принципів траєкторно-цільового підходу до прогнозування руху суден у рамках спільного управління інтелектуальними логіко-динамічними об'єктами. Сутність даного підходу складається у формуванні прогнозних траєкторій руху суден виходячи з заданих иільових позицій, а також критеріїв $і$ зон безпеки руху. Кожне судно представляється у виді взаємодіючого логікодинамічного об'єкта, щзо володіє иілеспрямованою поведінкою і реалізує траєкторію свого руху виходячи з принципів безпеки в умовах виконання вимог МППСС-72. Для моделювання даних прочесів доиільно використовувати агентноорієнтований підхід. Кожен агент (як інформаційна сутність) буде представляти судно, а система взаємодії агентів стане основою для формування правил системи підтримки прийняття рішення безпеки судноводіння. Використання запропонованого підходу побудови структури інтелектуального судна “A”- типу на принципах BDI дозволяє побудувати гнучку систему прийняття рішень, за допомогою якої може бути вироблене “краще рішення” попередження зіткнення суден, щуо задовольняє всі судна на всіх рівнях проектованої системи підтримки прийняття рішення безпеки судноводіння.

Ключові слова: агенти, безпека судноводіння, мультиагентні системи, система підтримки прийняття рішення, управління рухом, штучний інтелект.

\section{Вступ}

Постановка проблеми. Підвищення рівня автономності в сучасних людино-машинних системах (ЛМС), спроектованих за типом великих складних технічних об'єктів, призводить до розподілу центрів прийняття рішень. Це пов'язано з такими напрямками еволюції складних технічних систем, як децентралізація, прагнення до створення більш автономних за статусом об'єктів. На теперішній час для підвищення ефективності управляючої діяльності людини значні зміни відбулися в технічній підтримці прийняття рішень. З'явилися складні інтелектуальні системи, які допомагають моделювати об'єкти та навколишнє середовище; високоточні системи позиціювання водного транспорту; швидкодіючі обчислювальні комплекси, які здатні виконувати необхідні розрахунки в стислі терміни. Однак, незважаючи на наділення людини новими ресурсними можливостями для забезпечення безпеки ЛМС, очікуваний рівень аварійності та загибелі після впровадження нової техніки суттєво не зменшився. Причину таких невдач, насамперед, варто шукати в методах та підходах прийняття рішень. У складних технічних системах, до яких відноситься і водний транспорт, особа, яка приймає рішення на етапах вибору і прогнозування $\epsilon$ не тільки самою ненадійною, але і самою непередбачуваною ланкою.

Таким чином, основним шляхом у підвищенні ефективності прийнятих рішень людиною, на сучасному етапі розвитку техніки, є розробка та впровадження технологій підтримки прийняття рішень при управлінні водним транспортом, як складними активними технічними системами (АТС).

Система безпеки судноводіння (БС) $є$ ієрархічною слабоформалізуємою системою, яка є результатом взаємодії часто суперечних один одному по цілям функціонування елементів, і має множину неявних прямих і зворотних зв'язків. Для роботи в таких умовах проєктуєма система підтримки прийняття рішень (СППР) БС повинна містити ряд інформаційних баз знань (Б3): нормативну, експертну i 
прецедентну. Відмітимо, що реалізація процесу забезпечення БС представляє собою складну задачу кооперативної неантагоністичної взаємодії з розподіленим прийняттям рішень, для якої критично важливим стає забезпечення координації такої взаємодії в умовах цілеспрямованої поведінки учасників, що намагаються забезпечити безпеку руху. Рішення даного завдання в СППР БС може бути реалізоване 3 використанням принципів траєкторно-цільового підходу до прогнозування руху суден у рамках спільного управління інтелектуальними логікодинамічними об'єктами. Сутність даного підходу складається у формуванні СППР БС прогнозних траєкторій руху суден виходячи з заданих цільових позицій, а також критеріїв і зон безпеки руху. Кожне судно представляється у виді взаємодіючого логікодинамічного об'єкта, що володіє цілеспрямованою поведінкою і реалізує траєкторію свого руху виходячи 3 принципів безпеки в умовах виконання вимог МППСС-72. Для моделювання даних процесів доцільно використовувати агентноорієнтований підхід. Кожен агент (як інформаційна сутність) буде представляти судно, а система взаємодії агентів стане основою для формування правил СППР БС.

Аналіз останніх досліджень і публікацій. Проблемі аналізу, моделювання і управління активними системами присвячено значна кількість робіт як вітчизняних, так і закордонних авторів. Серед найбільш відомих потрібно відмітити авторів: Antoniou P., Baryam Yaneer, Boccara N., Chan S., Fiona A., Gareth W Parry, Haken H., Helton J., Holland J., Jennings N., Jing H., Koulouriotis D., Magee C., Scott A. DeLoach, Thunnissen D., Zhang D., Бусленко Н.П., Поспєлов Д.А., Володін В.В., Гриф М.Г., Дубов В.М., Каляєв И.А., Колісників А.А., Макаров И.М., Павлов В.В., Савін Г.И., Сафронов В.В., Силов В.Б., Новіков Д.А., Губко М.В., Максимов В.И., Кулінич А.А., у працях яких розглянуті питання формалізації знань, опису організаційних структур, побудови когнітивних моделей і розробки підходів, які здатні забезпечити необхідні показники якості управління складними АТС.

Основні підходи до моделювання мультиагентних систем із інтелектуальним поводженням на основі різних математичних апаратів досить докладно відображені в роботах В.І. Городецького, В.І. Варшавського, В.Б. Тарасова, О.В. Карасева, М. Вудриджа (M. Wooldridge), Н. Джепнингса (N. Jennings.), П. Мюллера (Р. Muller).

Однак практичне використання існуючих методів для побудови моделей СППР БС на основі мультиагентних систем вимагає проведення додаткових досліджень.

Метою статті $\epsilon$ розробка моделі реалізації системи підтримки прийняття рішення безпеки судноводіння на основі агентноорієнтованої технології.

\section{Виклад основного матеріалу}

Процес функціонування СППР БС складається 3 циклічного рішення наступної послідовності завдань:

- ідентифікація суден, що знаходяться в зоні можливого зіткнення;

- оцінка погрішності отриманих параметрів pyxy;

- класифікація суден за ступенем небезпеки;

- визначення множини взаємодіючих суден, для яких формуються можливі сценарії руху;

- визначення областей взаємних обов'язків суден, їх відповідність МППСС-72 і границь зони безпеки власного судна;

- формування множини можливих сценаріїв (стратегій) руху суден;

- визначення стратегій руху, що відповідають заданим критеріям безпеки;

- моделювання можливих сценаріїв розвитку навігаційної ситуації на основі принципів траєкторно-цільового управління;

- вироблення можливих альтернатив по управлінню судном і надання їх капітану.

Судно виключається з розгляду СППР БС при формуванні сценаріїв групової взаємодії у випадку ідентифікації його як безпечного, але моніторинг параметрів руху такого судна продовжується при перебуванні його в межах зони дії автоматизованої системи. Для небезпечних і потенційно небезпечних суден СППР формує багатокрокову стратегію розходження на весь прогнозований період їх перебування в зоні взаємних обов'язків, з наступною корекцією стратегії у випадку, якщо поточний розвиток ситуації буде відрізнятися від прогнозованого. У процесі формування стратегії розходження враховується передбачувана зміна параметрів руху суден, обумовлене їх взаємодією один з одним відповідно до МППСС-72 [1].

Результатом роботи СППР БС капітана є графічна візуалізація ситуації з вказівкою змін рекомендуємих параметрів руху власного судна [2].

Для побудови агентоорінтованої моделі СППР БС проведемо аналіз підсистем і дослідимо зміни в іiі компонентах, які необхідні для організації взаємодії між ними в локальних вузлах обробки інформації.

Основним завданням при побудові СППР БС $є$ створення середовища для рішення складних завдань БС, використовуючи механізм узгодження/консультацій між судами розподіленими в деякому географічному районі. Такий тип СППР БС можна віднести до СППР із розподіленим механізмом пошуку рішень. Елементом СППР БС є інтелектуальний агент. Приведемо таке визначення агента: “під агентом розуміється інформаційна сутність, 
наділена штучним інтелектом, здатна приймати рішення і обирати відповідно до нього свою поведінку в зовнішньому середовищі”. Дослідження організації СППР БС охоплюють весь спектр можливих взаємодій між судами-агентами, що, як правило, здатні до організації спільних дії для рішення конкретного завдання БС. На сучасному рівні формалізації системи БС, впровадження нових інформаційних, обчислювальних систем і технологічних рішень можна домогтися побудови СППР БС на принципах кооперації мультиагентних систем (МАС) $[3 ; 8]$.

Найбільш цікавою, 3 погляду застосування $\mathrm{MAC}, \epsilon$ задача прийняття рішення 3 попередження зіткнення суден (ЗПР ПЗС). Для розв'язання ЗПР ПЗС виникає необхідність узгодження дій (траєкторій розходження) двох або більш суден, причому 3 урахуванням стану внутрішньої структури кожного iз суден і впливу зовнішнього середовища який позначається на кожному із суден по-різному.

При цьому модель логічного виведення СППР БС, що представлена на рис. 1, відображає наступні етапи реагування [5-6]:

- якщо ситуація типова, то вироблення рекомендацій з управління за стандартним (формалізованим) шляхом - перехід судна в безпечний стан на основі інформації зворотного зв'язку про ступінь успішності управління (адаптація моделі);

- якщо ситуація якісно-нова, то здійснюється неформалізований пошук нового нестандартного рішення, а саме рішення формалізується і стає типовим (синтез моделі), тобто передається в майбутні стани.

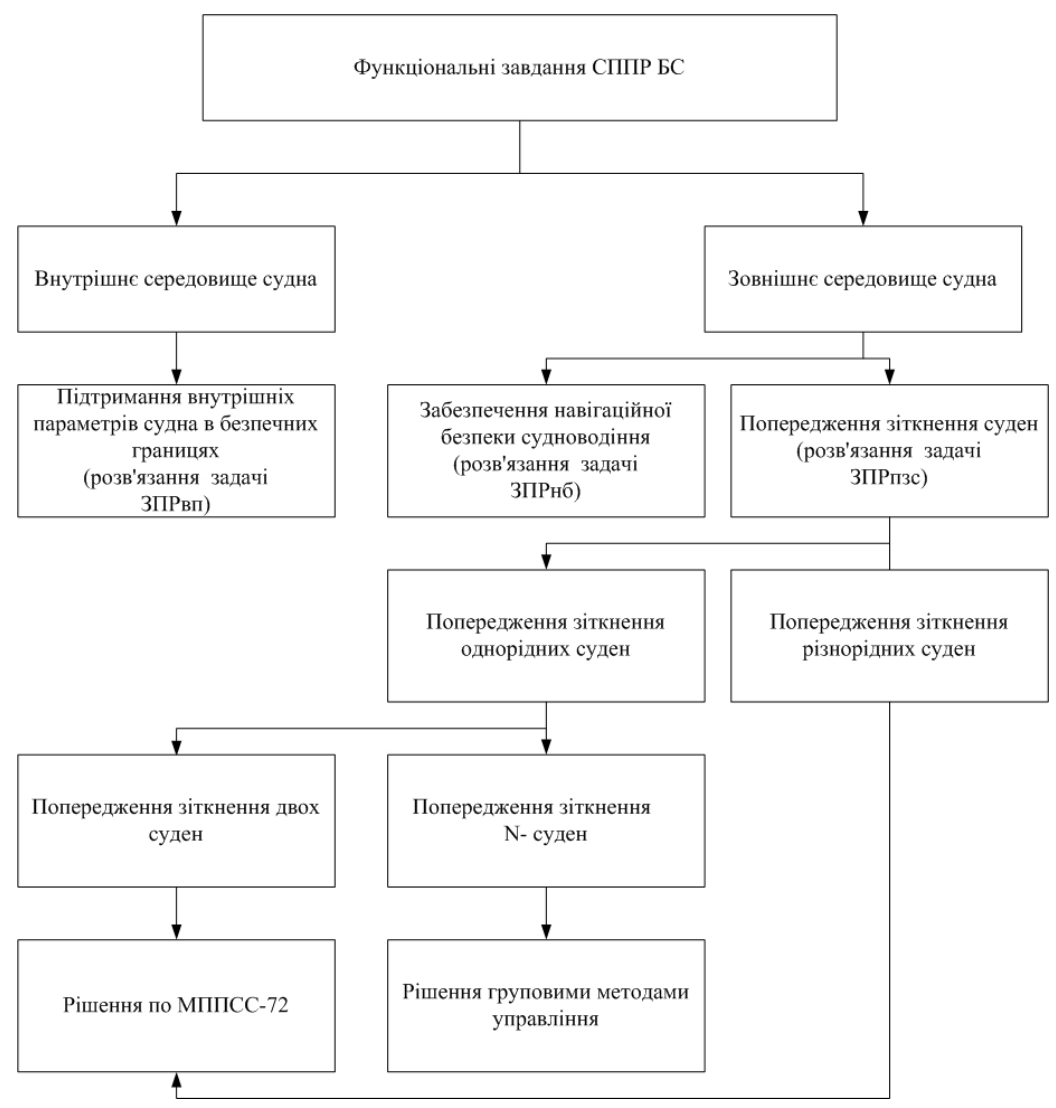

Рис. 1. Функціональні завдання СППР БС Джерело: розроблено авторами.

Необхідними умовами реалізації СППР БС виступають датчики інформації і технічних систем, що безпосередньо сприймають впливи зовнішнього середовища, виконавчі органи судна, а також процеcop - блок переробки інформації і пам'ять. Під пам'яттю тут розуміється здатність СППР БС зберігати інформацію про стан судна і стан середовища.

Рівень інтелектуальності судна залежить від його технічної забезпеченості. А відносини між суднами можуть будуватися за принципом "ведучийведений”. Нехай судно “А” - типу може приймати функції “ведучого” за наявністю інтегрованої мостикової системи (IBS). Такі судна завдяки технічним можливостям представлення зовнішнього середовища і можливостям базі знань та логічному висновку, можуть запам'ятовувати та аналізувати різні ситуації, передбачати можливі реакції на свої дії, робити 3 цього висновки, корисні для подальших дій і планувати свою поведінку. Саме розвинуті когнітивні здібності дозволяють таким судам будувати “віртуальні світи”, працюючи в яких вони формують плани дій. Інтелектуальні судна володіють добре 
розвинутою і поповнюваною символьною моделлю зовнішнього середовища, що досягається завдяки наявності в них бази знань, механізмів рішення й аналізу дій.

Для цілей організації МАС, що не володіють такого рівня інтелектуальністю, на маломірних суднах можливе використання Персональних систем навігації та моніторингу (СНM). Така система має вбудований GPS - приймач і високоякісну електронну картографію, що дозволяє легко орієнтуватися в море при будь-яких погодних умовах. Даний виріб може бути сполучений 3 захищеною радіолінією передачі даних про місце розташування маломірного судна, а також необхідною системою передачі інформації для організації кооперативної взаємодії між судами. У технічному забезпеченні маломірні судна на відміну від інтелектуального судна можуть не мати РЛС, САРП, гірокомпаса, датчиків кутової швидкості, метеостанції і т.д. У силу вищевказаних недоліків, такі маломірні судна мають обмежене бачення навколишнього середовища і діапазоном прогнозування. Зазначений тип суден можна віднести до комунікативного “веденого” судна-агента “В” - типу. У комунікативних суден модель зовнішнього середовища перетворюється головним чином у модель комунікації, що складається з моделей учасників процесу БС і бажаної мети.

Судно "А"- типу не тільки спостерігає і визначає за допомогою своїх інформаційних і фізичних датчиків параметри зустрічного судна, але і координує дії суден по каналах взаємного обміну інформацією. У результаті рівень невизначеності системи БС знижується і формується спільний план дій розходження суден. Цей план допускає “краще рішення” - сумісне рішення для всіх суден [7].

Розглянемо формування спільного плану розходження на безпечну відстані двох судів “А”- типу. Взаємна “домовленість” суден допускає обов'язок виконувати дії спільно. Однак колективні дії не можуть початися доти, поки між судами не буде досягнуто згоди, що конкретно буде робити кожне судно. Для вироблення такої угоди служить стадія формування спільного плану. Переговори є механізмом вироблення такої угоди. Протокол переговорів $є$ розподіленим алгоритмом пошуку угоди. На стадії формування спільного плану судна здійснюють спільні спроби домогтися такого стану кожного судна, у якому всі судна “А”- типу виробили б спільний план, згодні з ним, і мають намір діяти по ньому.

Під час переговорів судна “А”- типу генерують плани, уточнюють їх, модифікують запропоновані плани доти, поки усі судна не погодяться з єдиним кращим планом. При успішності завершенні попередньої стадії починається стадія спільних дій. У початковому стані стадії спільних дій між судами мається загальний план, і судна “A”- типу мають намір продовжувати спільні дії. При нормальному ході цього процесу дії виконуються відповідно до прийнятого плану аж до його завершення.

Викладені принципи формалізації процесу розходження на безпечну відстань суден приводять до розгляду СППР БС як класу багаторівневих багатоцільових систем. Клас багаторівневих багатоцільових систем характеризується наявністю ієрархічних відносин між органом, який приймає рішення та елементами даної системи. Існування Координатора, у даному випадку - відмінна риса такої системи. Проблема прийняття рішення на рівні Координатора $\epsilon$ основною проблемою при створенні СППР БС на принципах МАС.

Реалізація кооперативного рішення проблеми попередження зіткнення $\mathrm{N}$ - суден можлива з застосуванням мультиагентного підходу $[8,9]$. Для представлення цілісності процесу розходження судів будь-яких типів на принципах МАС потрібно:

- встановити ієрархічність “А”- типу, "В”- типу або "А" + "B”) ;

- виявити і формалізувати взаємозв'язок між внутрішніми і зовнішніми елементами.

В основі проектованої СППР БС розроблений підхід, в основі якого лежать принципи “ефективної і звичайної морської практики” і досвід застосування МППСС-72 [1], що мають широкі можливості у виборі ефективних дій відповідно до стану судна i зовнішнього середовища. При проектуванні СППР БС пропонується керуватися базовими засадами попередження зіткнення суден по МППСС-72, що полягають: судно здатне відслідковувати (Правило 5 Спостереження) “ту частину світу, що сприймається ним у сучасний момент”, визначати “існування небезпеки зіткнення” (Правило 7 Небезпека зіткнення) і приймати рішення, виходячи 3 внутрішнього стану судна (п. "b” Правило 2 Відповідальність) у виді простих логічних схем для попередження зіткнення суден (Правило 8 Дії для попередження зіткнення суден). Разом з тим судну потрібно не тільки опис існуючої ситуації, але так само інформація про мету дій, для попередження зіткнення 3 іншим суднами. “Дія ... повинна бути такою, щоб привести до розходження на безпечній відстані” (п. “d” Правило 8 Дії для попередження зіткнення суден), тобто потрібна інформація про те, на якій мінімальній відстані між судами $\left(D_{i}\right)$ може забезпечуватися безпечне розходження суден у тих або інших “обставинах та умовах плавання”. Якщо системи ПЗС відповідає встановленим стандартам поведінки самого судна та зовнішнього середовища за умови виконання МППСС-72, то функціональність даної моделі цілком підтверджується досягненням поставленої мети - розходження судів на $\left(D_{i}\right)$. При виробленні послідовності дій, судно повинне керуватися пошуком і плануванням своїх дій, для того щоб знання, на які 
спираються його рішення, могли бути модифіковані відповідно до конкретної ситуації зближення судів.

3 іншої сторони на ПЗС значно впливають умови плавання, наприклад, якщо видимість стає обмеженою, то судно повинне обновити свої знання про те, наскільки небезпечною стає ситуація зустрічі судів і які дій є кращими, виходячи з досвіду “ефективної морської практики”. Фактор “обмежена видимість” автоматично викликає скасування Правил 11-18 - Плавання судів на у видимості один одного і пропонує судну використовувати Правило 19 - Плавання при обмеженій видимості. У той же час Правила частини А - Плавання судів при будь-яких умовах видимості залишаються незмінними.

Таким чином, ПЗС представляє собою чергування ситуацій/періодів, протягом яких система поводиться то як детерміновано, то як невизначена. Тому особливе значення має завдання розробки адаптивної моделі вироблення рішень, тобто моделі, яка здатна легко перебудовуватися і зберігати високий ступінь адекватності як при зміні цільових i оцінних установок, так і стану судна і зовнішнього середовища.

Формалізація системи БС дозволяє реалізувати методологію побудови інтелектуального судна “А” - типу на принципах МАС. Основними структурними елементами судна “А” - типу є: зовнішнє середовище, корпус судна, система управління та інтелектуальні системи. Розглянемо ці елементи і їхні взаємозв'язки.

Зовнішнє середовище. Описувану модель зовнішнього середовища можна представити, як єдиний інформаційний простір:

$$
E I S=\left\langle X_{i}, K_{i}, G_{i j}, S\right\rangle,
$$

де $X_{i}$ - судно; $K_{i}$ - когнітивна модель $i$-го судна про зовнішнє середовище та самого себе, що реалізоване у вигляді інформаційного ресурсу; $G_{i j}$ характер інформаційної взаємодії $X_{i}$ та $X_{j}$ суден, де $i, j \in(1 \ldots N), N$ - кількість судів в просторі; $S$ $S$ - модель простору.

Сукупне відображення сприйняття зовнішнього середовища та підсистем самого судна здійснюється за допомогою Інтерфейсу, що є основою взаємодії всіх інформаційних підсистем СППР БС. Вхідна інформація Інтерфейсу формується на підставі технічних засобів судноводіння (рис. 2) відповідно до вимог конвенції SOLAS [10] у Главі V Правилом 19 "Вимоги до оснащення судів навігаційними системами та обладнанням”.

3 метою отримання, обробки і обміну інформацією повинні використовуватися дані існуючих радіотехнічних систем, як на судах, так і на берегових радіолокаційних станціях, що здійснюють моніторинг руху судів, і що мають обчислювальні пристрої для прогнозування дій по попередженню зіткнень. На рис. 2 наведено два типа обміну інформацією між судами для попередження зіткнення суден:

- достатній (суцільна подвійна стрілка);

- обмежений (пунктирна стрілка).

На рис. 2 позначено: ГНСС - глобальна навігаційна супутникова системи; РЛС - радіолокаційна станція; САРП - система автоматизованої радіолокаційної прокладки трас; АIC - автоматична ідентифікація судна.

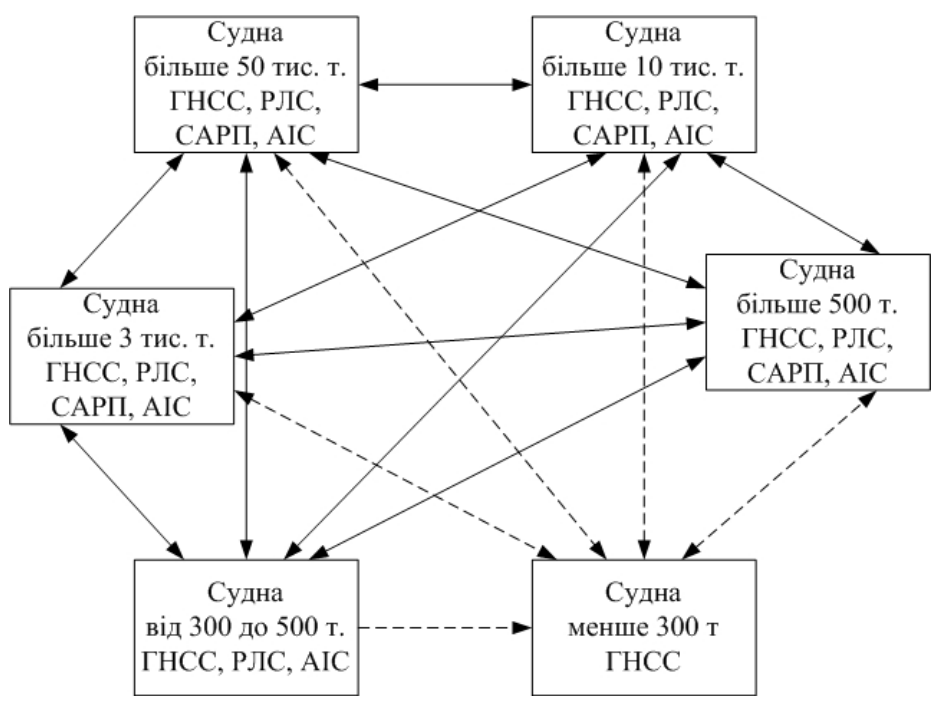

Рис. 2. Порядок обміну інформацією між судами різних типів Джерело: розроблено авторами.

Математична модель руху судна, як управляємо динамічна система $S(t)$ може бути представлена так:

$$
S(t)=F(t, C, S(0), U(t), L(t), E(t)),
$$
де $F$ - оператор, який характеризує конкретну математичну модель судна; 
$C$ - вектор постійних параметрів стану судна;

$S(0)$ - сукупність змінних параметрів, які описують стан судна в нульовий момент часу;

$U(t)$ - управляюча дія на судно в різні моменти часу;

$L(t)$ - функція завантаженості судна;

$E(t)$ - функція зовнішнього середовища та його впливу на судно (глибини в районі, швидкість вітру та течії, амплітудний та фазовий спектр хвилювання поверхні, спектр розповсюдження хвиль по акваторії за всіма частотами у часі, тощо).

Основними аспектами функціонування СППР БС, насамперед, є: цілеполягання, прогнозування, планування і узагальнення досвіду. Для опису стану судна $з$ метою попередження зіткнення суден особливе значення має завдання прогнозування і побудови алгоритму руху судна на предмет необхідного маневру розходження судів $U(t)$ при відомих $C, F, S(t), L(t), E(t)$.

Підсистема обробки інформації та підсистема генерування рішень (процесор) виконує безпосередній та явно виражений локальний вплив на підсистеми, забезпечуючи безпеку плавання і маневрування. При цьому одним з найбільш важливих аспектів $\epsilon$ сполучення цілеполягаючої і реактивної функцій, що здійснює діяльність у динамічному нечіткому середовищі. Сполучення цих двох функцій здійснюється через динамічну зміну ситуації, сформованої судном “А”- типу для розходження $\mathrm{N}$ - суден на заданій відстані $D_{i}$. Розроблена модель СППР БС представляється складною багаторівневою ієрархією обробки інформації та вироблення рішень з використанням загальної бази знань.

Дана структура відповідає ідеї агента, заснованого на принципах Переконання-Бажання-Намір (Belief-Desire-Intention) (BDI) [8], що використовує точне представлення картини світу в символьній формі, а рішення приймаються на основі формальних міркувань та використання методів порівняння за зразком (деліберативні агенти).

Робота судна на принципах BDI починається 3 кінцевої множини станів навколишнього середовища: $E=\left\{e_{1}, e_{2}, \ldots ., e_{n}\right\}$ і заснована на виборі стереотипних методів досягнення мети відповідно до розпізнаної ситуації, описаної в МППСС-72 на основі продукційних правил типу “якщо..., то ....”.

У випадку існування небезпеки зіткнення однорідної групи судів “A”- типу (якщо N>2) пропонується використовувати методи координації за допомогою протоколу обміну інформацією. Судна обмінюються один з одним інформацією за допомогою переговорів. Протокол взаємодії групи судів визначає схему (розподілений алгоритм), по якій ведуться такі переговори. Якщо позначити множину сприйняття - P, множину станів зовнішнього середовища $\mathrm{E}$, а множину дій судна - А, то правила для судна 3 метою попередження зіткнення матиме вигляд:

$$
\operatorname{des} \subseteq T \arg e t(P, E, A) .
$$

Судно, що реалізує принципи BDI, вибирає специфічні дія 3 доступної множини можливих дій невизначеності ситуації $A=\left\{a_{1}, a_{2}, \ldots, a_{n}\right\}$ та намагається знайти та виконати кращий план $\pi$, що $€$ серією дій, виконаних в деякому порядку.

Однією з відмітних властивостей даної моделі є здатність судна "А” - типу до побудови планів взаємодії з навколишнім середовищем. Плани являють собою визначені дії судна, що зберігаються в бібліотеці дій планів, що воно запускає для пошуку більшої кількості планів, щоб досягти розходження на безпечній відстані $D_{i}$.

У залежності від поточної ситуації вибирається відповідний план дії для виконання. Якщо специфічний план досягнення мети зазнає невдачі, то вибирається інший план досягнення мети з усіх можливих планів. Процес пошуку закінчується знаходженням допустимого плану. Для розв'язання конфліктів у “існуючих обставинах і умовах плавання" необхідно визначити міру сумісності дій для попередження зіткнення $\mathrm{N}$ - судів на всіх рівнях ієрархії. Процес оновлення $\operatorname{des}^{\prime} \subseteq T \arg \operatorname{et}(P, E, A)$ можна змоделювати відповідною функцією (drf - desires revision function).

Функція перегляду переконань (brf) модифікує поточні переконання судна "A" - типу на основі множини всіх переконань Bel (як внутрішніх, так i зовнішніх), а також поточних результатів пізнавального процесу (перцепції Per):

$$
\text { brf : }(\mathrm{Bel}) \times \mathrm{Per} \rightarrow \mathrm{Bel} .
$$

“Інтерпретатор дій” здійснює перерахунок (ітерування) керуючих впливів, що задовольняє всіх учасників ПСС, по ходу взаємного обміну інформацією про виконання управляючих дій для розходження з іншими судами за формулою (2) для досягнення на виході стану судна за формулою (3), що будуть задовольняти всіх учасників ПСС і можуть бути безпосередньо реалізовані виконавчими механізмами судна.

\section{Висновки}

Використання запропонованого підходу побудови структури інтелектуального судна "A" - типу на принципах BDI дозволяє побудувати гнучку систему прийняття рішень, за допомогою якої може бути вироблене “краще рішення” попередження зіткнення суден, що задовольняє всі судна на всіх рівнях проектованої СППР БС.

СППР БС можна представити як мережеву 
структуру, яка складається з окремих судів-агентів 3 розподіленим принципом прийняття рішень. База знань кожного судна має багаторівневу структуру 3 діючими правилами ПСС. Кожне судно має опис можливих і заборонених дій, що визначають його роль у рішенні глобального завдання ПСС. План дій усіх судів формується шляхом синтезу результатів роботи кожного судна-агента.

СППР БС охоплюють весь спектр можливих взаємодій між агентами, що, як правило, здатні до організації спільних дії для розв'язання конкретної задачі безпеки. 3 урахуванням можливостей технічних засобів судноводіння, що маються в даний час на судах, для забезпечення безпеки плавання може застосовуватися технологія заснована на кооперації судів-агентів на принципах МАС щодо досягнення спільного плану дій. Переговори є механізмом вироблення такого плану, застосований при цьому протокол переговорів є розподіленим алгоритмом пошуку угоди.

\section{Список літератури}

1. Международные правила предупреждения столкновений судов в море 1972 (МППСС-72) [Електронний ресурс]. - М.: РКонсульт, 2004. - 80 с. - Режим доступу: http://www.mppss.ru/rules/

2. Месарович М. Теория иерархических многоуровневых систем: пер. с англ. / М. Месарович, Д. Мако, И. Тахакара. - М.: Мир, 1973. - 344 с.

3. Прохоров А.В. Облачная платформа разработки интеллектуальных систем поддержки принятия решений / А.В. Прохоров, В.П. Прохоров, А.О. Матюшко // Вісник Харківського політехнічного інституту. - 2015. - № 58(1167). C. $72-76$.

4. Методологические аспекты функционирования системы поддержки принятия решений в рамках интеллектуальной системы ситуационного центра / В.С. Симанков, С.Н. Владимиров, А.О. Денисенко, А.Н. Черкасов // Вестник Адыгейского государственного университета. - 2015. - № 4(171). - С. 133-138.

5. Щербатов И.А. Управление группой роботов: компонентный подход / И.А. Щербатов, И.О. Проталинский, О.М. Проталинский // Информатика и системы управления. - 2015. - № 1(43). - С. 93-104.

6. Astrein V. Determination of ships passing strategy by the use of a conflict function / V. Astrein // Eurasian Union of Scientists. - 2015. - № 12(21). - C. 1-3.

7. Шерстюк В.Г. Интеллектуальные системы поддержки принятия решений по управлению судном в условиях неполной и противоречивой информации / В.Г. Шерстюк, А.П. Бень // Судовождение. - 2007. - № 14. - С. 141-144.

8. Городецкий В.И. Прикладные многоагентные системы группового управления / В.И. Городецкий, О.В. Карсаев // Искусственный интеллект и принятие решений. - 2009. - № 2. - С. 3-24.

9. Гуревич Л.А. Мультиагентные системы / Л.А. Гуревич, А.Н. Вахитов. - М.: ВБГТУ, 2005. - 116 с.

10. SOLAS: Consolidated text of the International Convention for the Safety of Life at Sea, 1974, and its Protocol of 1988 : articles, annexes and certificates: IMO: 2004 edition [Електронний ресурc]. - London.: IMO publication, 2005. - P. 565. - Peжим доступу: http://www.imo.org/en/About/Conventions/ListOfConventions/Pages/International-Convention-for-the-Safety-ofLife-at-Sea-(SOLAS),-1974.aspx.

11. Астреин В.В. Основы интеллектуальных систем предупреждения столкновений судов: монография / В.В. Астреин. - Saarbrucken: Lambert Academic Publishing, 2014. - 109 c.

12. Коккрофт А.Н. Толкование МППСС-72: пер. с англ. / А.Н. Коккрофт, Д.Н. Ламейер. - М.: Транспорт, 1981. $279 \mathrm{c}$.

Надійшла до редколегї 29.07.2020

Схвалена до друку 22.09.2020

\section{Відомості про авторів:}

\section{Дакі Олена Анатоліївна}

доцент

Державного університету інфраструктури та технологій, Київ, Україна

https://orcid.org/0000-0003-3932-462X

\section{Дорошева Антоніна Олександрівна}

доцент

Державного університету інфраструктури та технологій, Київ, Україна

https://orcid.org/0000-0003-3257-7173

\section{Іваненко Віталій Миколайович}

старший викладач

Державного університету

інфраструктури та технологій,

Київ, Україна

https://orcid.org/0000-0003-3271-5257

\section{Information about the authors:}

\section{Olena Daki}

Senior Lecturer

of State University of Infrastructure and Technology,

Kyiv, Ukraine

https://orcid.org/0000-0003-3932-462X

\section{Antonina Dorosheva}

Senior Lecturer

of State University of Infrastructure and Technology,

Kyiv, Ukraine

https://orcid.org/0000-0003-3257-7173

\section{Vitaliy Ivanenko}

Senior Instructor

of State University

of Infrastructure and Technologies,

Kyiv, Ukraine

https://orcid.org/0000-0003-3271-5257 
Чебан Валерій Іларіонович

старший викладач

Державного університету інфраструктури та технологій, Київ, Україна

https://orcid.org/0000-0001-9662-8617

\section{Valeriy Cheban}

Senior Instructor

of State University of Infrastructure and Technologies,

Kyiv, Ukraine

https://orcid.org/0000-0001-9662-8617

\section{АГЕНТООРИЕНТИРОВАННАЯ МОДЕЛЬ РЕАЛИЗАЦИИ СИСТЕМЫ ПОДДЕРЖКИ ПРИНЯТИЯ РЕШЕНИЯ БЕЗОПАСНОСТИ СУДОВОЖДЕНИЯ}

Е.А. Даки, А.А. Дорошева, В.Н. Иваненко, В.И. Чебан

В статье рассмотрены модели и методы построения системы поддержки принятия решения безопасности судовождения с использованием мультиагентных систем, что соответствует современному направлению развития интеллектуальных информационных технологий - построения агентоориентированных систем. Определено, что система безопасности судовождения является иерархической слабоформализуемой системой, которая является результатом взаимодействия часто противоречащих друг другу по иелям функичонирования элементов, и имеет множество неявных прямых и обратных связей. Использование предложенного подхода построения структуры интеллектуального судна “A” - типа на принциипах BDI позволяет построить гибкую систему принятия решений, с помощью которой может быть произведено “лучшее решение” предупреждения столкновения судов, удовлетворяющее все суда на всех уровнях проектируемой системы поддержки принятия решения безопасности судовождения.

Ключевые слова: агенты, безопасность судовождения, мультиагентные системы, система поддержки принятия решения, управление движением, искусственный интеллект.

\section{AGENT-ORIENTED MODEL OF IMPLEMENTATION OF THE DECISION SUPPORT SYSTEM FOR THE SAFETY OF NAVIGATION}

O. Daki, A. Dorosheva, V. Ivanenko, V. Cheban

The article discusses models and methods for building a decision support system for navigation safety using multi-agent systems, which corresponds to the modern direction of development of intelligent information technologies - building agentoriented systems. It has been determined that the navigation safety system is a hierarchical weakly formalized system, which is the result of the interaction of elements that often contradict each other in terms of the goals of their functioning, and has many implicit direct and feedback connections. To work in such conditions, the projected decision support system must contain a number of information knowledge bases: normative, expert and precedent. It is noted that the implementation of the process of ensuring the safety of navigation is a complex task of cooperative non-antagonistic interaction with distributed decision-making, for which it becomes critically important to ensure the coordination of such interaction in the conditions of purposeful behavior of participants trying to ensure traffic safety. The solution to this problem can be implemented using the principles of the trajectorytarget approach to predicting the movement of ships in the framework of joint management of intelligent logical-dynamic objects. The essence of this approach consists in the formation of predictive trajectories for the movement of vessels based on the specified target positions, as well as criteria and traffic safety zones. Each ship is represented as an interacting logical-dynamic object with purposeful behavior and realizes its trajectory based on the principles of safety while meeting the requirements of the MPPSS-72. To model these processes, it is advisable to use an agent-based approach. Each agent (as an information entity) will represent a ship, and the agent interaction system will become the basis for the formation of rules for the decision support system for navigation safety. Using the proposed approach to constructing the structure of an intelligent ship " $A$ " -type on the principles of BDI allows you to build a flexible decision-making system, with the help of which the "best solution" for collision avoidance can be produced that satisfies all ships at all levels of the projected navigation safety decision support system.

Keywords: agents, artificial intelligence, decision support system, navigation safety, multi-agent systems, traffic control. 